\begin{tabular}{|c|c|}
\hline \multirow{3}{*}{ 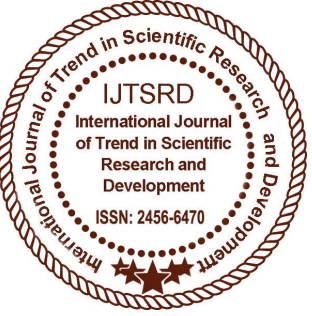 } & $\begin{array}{l}\text { International Journal of Trend in Scientific } \\
\text { Research and Development (IJTSRD) }\end{array}$ \\
\hline & International Open Access Journal \\
\hline & ISSN No: 2456 - 6470 | www.ijtsrd.com | Volume - 2 | Issue - 5 \\
\hline
\end{tabular}

\title{
Biochemical Composition and Liver Somatic Index Studies on Carps of Tawa and Halali Reservoirs in Bhopal, India
}

\author{
Sanjay Waghode ${ }^{1}$, Leena Muralidharan ${ }^{2}$ \\ ${ }^{1}$ Student, Ramniranjan Jhunjhunwala College of Arts, Science \& Commerce, \\ Ghatkoper(W), Mumbai, Maharashtra, India \\ ${ }^{2}$ Associate Professor, Department of Zoology, V.K.Krishna Menon College of Commerce and Economics and \\ Sharad Shankar Dighe College of Science, Bhandup (E), Mumbai, Maharashtra, India
}

\begin{abstract}
Body composition is an analysis of carbohydrates, proteins, and moisture and ash contents of fish. The body composition was studied using as an index of growth studies of Indian major carp's Catla, Rohu and Mrigala and a minor carp Cyprinus carpio in the Halali and Tawa Reservoirs. The protein and lipid contents of three fish species showed the successive decrease in their estimated values, whereas muscle glycogen content in fish species understudy showed a significant increase during the study. The variation of Liver somatic index observed could be due to increased metabolic activity. Considering the fact of comparatively low-fat content all four species were found to be an ideal food for human being.
\end{abstract}

Keywords: glycogen, protein, lipid, moisture, LSI

\section{INTRODUCTION}

An important contribution has been made on the study of the body composition and their caloric values of different fresh water fishes by several workers. Body composition of different types of fishes was also explained by Peyami et al., (2006). Singh et al., (2006); Khan and Abidi, (2010); Ahmed, (2011) and Noor Khan et al., (2011), Shaik et.al (2011). Fish of various species do not provide the same nutrient profile to their consumer (Takama et.al. 1999) and also the nutritive value of fish varies with season. The present study was carried for the body composition of Indian major carp's Catla, Rohu and Mrigala and a minor carp Cyprinus carpio using the body composition as an index of growth studies in the Halali and Tawa Reservoirs.

\section{Materials and Methods:}

Matured fishes were collected from Tawa \& Halali reservoir mainly by using gill nets of different mesh sizes, which varied from 10 to $1000 \mathrm{~mm}$ with the assistance of local fishermen at regular intervals about once in a month during the investigation period from Tawa and Halali reservoirs. Each catch was handled separately and sorted by species and processed for biochemical estimations as described by (Plummer D.T. 1985). Fish were identified with standard fish identification on key (Jayaraman 2002; Jingran V.A. 1991). The samples were packed in separate polyethylene bags, and labelled for further laboratory analysis.

The glycogen content of liver and muscle tissues was estimated by Anthrone method. The optical density was read at $625 \mathrm{~m} \mu$ on spectronic-20 (Baush \& Lomb model No. 33-31-72). The method suggested by Lowry, et al. (1951) was opted for the determination of soluble protein contents in liver and muscle tissues. The optical density was read at $500 \mathrm{~m} \mu$ on spectronic20. Total lipid content of dry liver and muscle tissue samples was estimated gravimetrically following the method of Folch et al. (1957). Moisture was determined according to the method given on A.O.A.C. (1975). A known weighed quantity of muscle and liver tissues was dried in an oven at $90^{\circ} \mathrm{C}$ for 24 to 36 hours. The dried tissue was weighed again. The moisture content was calculated from the loss in weight. 
International Journal of Trend in Scientific Research and Development (IJTSRD) ISSN: 2456-6470

$\%$ Moisture $=\frac{\text { Loss in wt of tissue }}{\text { Wet weight of tissue }} \times 100$

Liver somatic index was calculated from the following formula:

$$
\% \text { LSI }=\frac{\text { Wt of tissue }}{\text { Weight of body }} \times 100
$$

Moisture, lipid, protein and glycogen, LSI content of three species of fish were first analyzed by one way analysis of variance (ANOVA).

\section{Results and Discussion:}

The collected samples ranged from $35-45 \mathrm{~cm}$ standard length and body weight ranged from 720 $1000 \mathrm{~g}$. The moisture, protein, lipid and glycogen contents in the muscle and liver tissues of fishes selected from Tawa and Halali reservoirs were examined and presented in Table 1-4. Each value indicates the mean $+\mathrm{SD}$ of twenty four replicate determinations.

Glycogen is a branched polymer of glucose and is the storage form of carbohydrate for every organism from yeast to primates. The major glycogen stores in vertebrates exist in liver and muscle. Glycogen stored in liver can be made accessible to other organs by virtue of their possession of an enzyme glucose 6phosphatase. Muscle cells usually lack this enzyme and therefore muscle glycogen is considered to be an available to other cells outside muscle tissue. From the table 1 it is evident that very limited variation in proximate composition occurs in all fishes. Glycogen levels are found to be highest in liver as it is the chief organ of carbohydrate metabolism in animals followed by muscles. Liver glycogen is storage and export of hexose unit and that of muscle glycogen is to act as readily available source of hexose unit for glycolysis with in the muscle itself. A fall in the glycogen level clearly indicates its rapid utilization to treat the enhanced energy demands in fish.

Muscles rich in protein, form mechanical tissue intended for mobility and do not participate in metabolism. Liver being the centre for various metabolisms is also rich in protein. Decreased in the protein content could be due to the production of heat shock proteins or destructive free radicals. Although slight monthly variations were observed for summer and rainy seasons protein levels were not statistically different in the fish. High tissue protein content may result from equally high protein content of their diet.
Lipids are storage from of energy like glycogen. Fish with lipid content below 5\% are considered to be lean (Ackman 1989). Hence the lipid content in carps studied also falls within the range. Low concentration of lipid in muscles could be due to poor storage mechanism and use of fat reserves during spawning activities. . Moisture content and lipid content in all the fishes are inversely related and their sum is approximately $80 \%$ (FAO 1999). The maximum lipid content of the fishes $2.57 \%$. It is much lesser in C.Mrigale and least in C.Carpio. From the table1-4 it is seen that fat and moisture are internally correlated though striking seasonal variation, higher fat content with in a year generally occurs in July and October since this fish breeds during monsoon. It appears that this limited build up of fat is to provide the energy. Liver is the centre of metabolism and is the main and important detoxifying organ in fish. It is essential for both the metabolism and the excretion of toxic substances. Liver somatic index is general measurement of overall condition of fish or the growth status of liver and can be an excellent prediction of adverse health in fish. The proximate composition of test fishes collected form Tawa \& Halali reservoirs shows species specific patterns in their muscle and liver protein, glycogen and lipid contents. The protein and lipid contents of three fish species showed successive decrease in their estimated values, where as muscle glycogen content in fish species understudy shown significant increase during the study. The fluctuations in biochemical composition of muscles of fish species may also be attributed to alteration in the ecology of the sampling site of the reservoir .Similarly during August to June the muscle protein \& lipid contents in three fish species showed successive decrease in their values whereas glycogen content in muscle showed increasing trend during the same period (Table1-4). This could be due to increased glycogenesis in muscles and accelerated conversion of liver glycogen into muscle glycogen during the period (Padmavati.G. et. al. 2006). The observation indicated that variations were not only species specific and season specific but it is also linked to their ecological habitat and nutritive values (Chamundeshwari Devi et. al. 2001).

\section{Conclusion}

Fish play an important role in human nutrition in India particularly to the people of coastal areas. Good and adequate nutrition plays an important role in expression of mental, physical and intellectual 
qualities in human. In term of lipid contents of the fish species examined it can be concluded that all form species of fish studied are lean fat fish. All the four fish species selected for the study from tawa and halali are found to be preferable food for human consumption because of its high protein content in the flesh (table1-4). Considering the fact from table 1-4 of comparatively low fat content all four species are ideal food for human being. The total lipid and ash content of fish are reported to vary considerable due to seasonal changes aside from nutrients in varied habitats . Although hepatosomatic index can vary with nutrition, season, fish conditions possible interpretation of a variation of hepatosomatic index can be due to increased metabolic activity.

\section{References:}

1. Ackman. R. G, 1989, Nutritional composition of fats in sea foods, Prog. Food Nutr. Sci., 13: $161-$ 289.

2. Ahmed. I. Effect of dietary niacin on growth and body composition of two Indian major carps, Rohu, Labeo rohita and Mrigale, Cirrviunus mrigale fingerlings bases on dase-response study. Aquaculture, Int., 19, 2011, 567 - 584.

3. Albrektsen S, Mudheim H, Aksnes A; Growth, feed efficiency, digestibility and nutrient distribution on Atlantic cad (Gadus morhuo) fed two different fish meal qualities as three dietary levels of vegetable protein sources, Aquaculture, 261, (2006), 626-640.

4. Berg O. K, Thronaes. E, Bremset G. Seasonal changes in body composition in young riverine Atlantic salmon and brown trout, J. Fish Biol, 52, (2000), $1272-1288$.

5. Chamundeshwari Devi and Vijayarasahwan. S. 2001: Biochemical soyabean and Glyeine based diets with lysine and methionine. J. Aqua. Bio. 16(2): $81-83$.

6. Folch J., Less, Stanley G. H. S (1957). A simple method for the isolation and purification of total lipids from animal tissues. J. Biol. chem. 226: $497-509$.

7. Food and Agriculture Organization 1999. World Production of fish Crustaceans and molluscs by major fishing areas. Fisheries Information Data and Statistics Unit (FIDI), Fisheries Department, FAO Rome, 33pp.
8. Jayaram. K. C. 2002. The fresh water fishes of the Indian region. Narendra Publishing House, Delhi.

9. Jingran. V. G. 1991. Fish and fisheries of India. Hindustan Publishing Corporation. Plummer. D. T. 1985. In An Introduction to Practical Biochemistry, IInd edition. Tata McGraw - Hill Publi. Camp, New Delhi.

10. Khan M. A, Abidi S. F, Optimum ration level for better growth, conversion officiencies and body composition of fingerling Heteropneustes fossilis (Baloch). Aquaculture International, 18, (2010), $175-188$.

11. Lowry O. H, Rosenbrough N. J, Farr R. L, Randall R. J. 1951. Protein measurement with the Folin phenol reagent. J. Biol. Chem. (193): $265-275$.

12. Noor Khan, Naureen A. Qureshi, Grant W. Vandenberg, Pallab K. Sankar, Muhammad, Ashraf, Fayyaz Rasool . 2011. Performance and body composition of Indian major carps (Catla Catla, Cirrhinus mrigala and Labeo rohita) fingerlings when fed and antificial feed under monoculture production. International Journal of cell \& molecular Biology, 2 (3), 689 - 700.

13. Padmawati. G. and Prema Kumar. R. 2006. Impact of starvation on tissue lipid content in climbing perch, Anabas testudineus. J. Aqua. Biol. 21(2): $147-150$.

14. Peyami. F. Y., Afsen. M. R, Nisar. S. K. and Anis. A. B, choudary, Body composition and caloric value of a teleostean fish, Etropiichthys vacha (Ham.), Aquaculture 7 (1); (2006, 111 - 116.

15. Shaikh A, Prakash S L (2011); Biochemical composition and Gonado Somatic Index of Three major carps in Hatnoor reservoir, (M. S), India. J. $\begin{array}{lllll}\text { Ecobiotechnology } & 3(6): & 01 & - & 04 .\end{array}$ www.cholarjurnal.org.

16. Singh P. K, Gaur S. R, Chari M.S. Effect of varying protein levels on the growth of Indian major carp Rohu, Labeo rohita (Hamilton (. International Journal of Zoological Research, 2(2), (2006), 186 - 191.

17. Takma, K. T., Suzuki, K. Yoshida H. Azai and T. Mitsui, 1999. Phosphatidylcholine levels and their fatty acid compositions in teleost tissues and squid muscle. Comp. Biochem. Physiol. Part B: Biochem. Mol. Biol. 124: 109 - 116. 
International Journal of Trend in Scientific Research and Development (IJTSRD) ISSN: 2456-6470

Table 1 Bio-chemical Composition in the muscle of three major carps and a minor carp collected from Halali Reservoir.

\begin{tabular}{|c|c|c|c|c|c|c|}
\hline Sr. No. & Fish Species & Season & Protein & Glycogen & Lipid & Moisture \\
\hline \multirow{3}{*}{1} & \multirow{3}{*}{ Cirrhinus Mrigala } & Rainy & $15.53 \pm 0.4$ & $1.97 \pm 0.5$ & $1.77 \pm 0.7$ & $77.82 \pm 0.12$ \\
\cline { 3 - 7 } & & Winter & $14.23 \pm 0.9$ & $2.23 \pm 0.8$ & $1.37 \pm 0.3$ & $75.67 \pm 0.16$ \\
\cline { 3 - 7 } & & Summer & $13.34 \pm 0.5$ & $2.84 \pm 0.4$ & $1.07 \pm 0.6$ & $74.30 \pm 0.11$ \\
\hline \multirow{3}{*}{2} & \multirow{3}{*}{ Labeo Rohita } & Rainy & $18.33 \pm 1.0$ & $2.53 \pm 0.6$ & $2.57 \pm 1.0$ & $75.42 \pm 0.2$ \\
\cline { 3 - 7 } & & Winter & $17.51 \pm 0.8$ & $2.74 \pm 0.3$ & $2.04 \pm 0.6$ & $74.66 \pm 0.6$ \\
\cline { 3 - 7 } & & Summer & $16.30 \pm 0.3$ & $3.13 \pm 0.5$ & $1.53 \pm 0.5$ & $74.42 \pm 0.3$ \\
\hline \multirow{3}{*}{3} & \multirow{3}{*}{ Catla Catla } & Rainy & $15.70 \pm 0.4$ & $2.23 \pm 0.5$ & $2.11 \pm 0.6$ & $75.00 \pm 0.17$ \\
\cline { 3 - 7 } & & Winter & $14.07 \pm 0.8$ & $2.66 \pm 0.4$ & $1.67 \pm 0.6$ & $74.76 \pm 0.21$ \\
\cline { 3 - 7 } & & Summer & $13.47 \pm 0.4$ & $2.80 \pm 0.6$ & $1.34 \pm 0.3$ & $74.06 \pm 0.32$ \\
\hline \multirow{3}{*}{4} & \multirow{3}{*}{ Cyprinus Carpio } & Rainy & $17.6 \pm 0.6$ & $1.58 \pm 0.31$ & $0.71 \pm 0.3$ & $78.01 \pm 0.2$ \\
\cline { 3 - 7 } & & Winter & $16.6 \pm 0.5$ & $1.18 \pm 0.25$ & $0.68 \pm 0.6$ & $73.70 \pm 0.30$ \\
\cline { 3 - 7 } & & Summer & $13.5 \pm 0.4$ & $1.05 \pm 0.40$ & $0.51 \pm 0.5$ & $71.85 \pm 0.15$ \\
\hline
\end{tabular}

Table 2.Bio-chemical Composition in the muscle of three major carps and a minor carp collected from Tawa Reservoir.

\begin{tabular}{|c|c|c|c|c|c|c|}
\hline Sr. No. & Fish Species & Season & Protein (\%) & Glycogen (\%) & Lipid (\%) & Moisture (\%) \\
\hline \multirow{3}{*}{1} & \multirow{3}{*}{ Cirrhinus Mrigala } & Rainy & $17.47 \pm 0.3$ & $1.69 \pm 0.4$ & $1.80 \pm 0.8$ & $79.35 \pm 1.23$ \\
\cline { 3 - 7 } & & Winter & $15.61 \pm 0.2$ & $2.26 \pm 0.5$ & $1.40 \pm 0.3$ & $75.00 \pm 2.14$ \\
\cline { 3 - 7 } & & Summer & $14.07 \pm 0.5$ & $2.67 \pm 0.4$ & $1.06 \pm 0.6$ & $72.060 \pm 2.77$ \\
\hline \multirow{3}{*}{2} & \multirow{3}{*}{ Labeo Rohita } & Rainy & $18.39 \pm 0.5$ & $2.67 \pm 0.8$ & $2.70 \pm 1.0$ & $78.61 \pm 0.75$ \\
\cline { 3 - 7 } & & Winter & $17.66 \pm 0.6$ & $3.20 \pm 0.4$ & $2.09 \pm 0.5$ & $77.68 \pm 0.12$ \\
\cline { 3 - 7 } & & Summer & $17.20 \pm 0.4$ & $3.51 \pm 0.2$ & $1.47 \pm 0.5$ & $77.05 \pm 0.16$ \\
\hline \multirow{3}{*}{3} & \multirow{3}{*}{ Catla Catla } & Rainy & $16.89 \pm 0.3$ & $2.40 \pm 0.6$ & $2.07 \pm 0.5$ & $78.01 \pm 1.03$ \\
\cline { 3 - 7 } & & Winter & $14.86 \pm 0.8$ & $2.81 \pm 0.2$ & $1.69 \pm 0.6$ & $77.82 \pm 0.5$ \\
\cline { 3 - 7 } & & Summer & $14.04 \pm 0.3$ & $3.11 \pm 0.3$ & $1.37 \pm 0.3$ & $74.62 \pm 0.8$ \\
\hline \multirow{3}{*}{4} & \multirow{3}{*}{ Cyprinous Carpio } & Rainy & $18.20 \pm 0.6$ & $1.68 \pm 0.31$ & $0.92 \pm 0.3$ & $83.6 \pm 0.7$ \\
\cline { 3 - 7 } & & Winter & $17.60 \pm 0.8$ & $1.58 \pm 0.46$ & $0.75 \pm 0.5$ & $78.0 \pm 0.3$ \\
\cline { 3 - 7 } & & Summer & $17.45 \pm 0.5$ & $1.54 \pm 0.5$ & $0.71 \pm 0.2$ & $73.7 \pm 0.6$ \\
\hline
\end{tabular}

Table 3.Bio-chemical Composition in Liver of three major carps and a minor carp collected from Halali Reservoir.

\begin{tabular}{|c|c|c|c|c|c|c|c|}
\hline Sr. No. & Fish Species & Season & Protein & Glycogen & Lipid & Moisture & LSI \\
\hline \multirow{3}{*}{1} & \multirow{3}{*}{ Cirrhinus Mrigala } & Rainy & $28.7 \pm 2.8$ & $23.8 \pm 3.2$ & $12.4 \pm 5.2$ & $37.82 \pm 0.12$ & $2.238 \pm 0.61$ \\
\hline & & Winter & $29.6 \pm 6.4$ & $25.6 \pm 5.6$ & $9.6+2.0$ & $35.67 \pm 0.16$ & $2.395 \pm 0.67$ \\
\hline & & Summer & $23.4 \pm 3.6$ & $29.9 \pm 3.0$ & $7.5 \pm 4.3$ & $34.30 \pm 0.11$ & $2.399 \pm 0.62$ \\
\hline \multirow{3}{*}{2} & \multirow{3}{*}{ Labeo Rohita } & Rainy & $28.3 \pm 6.8$ & $27.7 \pm 4.2$ & $18.0 \pm 7.3$ & $35.42 \pm 0.2$ & $2.075 \pm 0.49$ \\
\hline & & Winter & $22.6 \pm 5.3$ & $29.2 \pm 2.3$ & $14.3 \pm 4.3$ & $34.66+0.6$ & $2.174 \pm 0.46$ \\
\hline & & Summer & $24.1 \pm 2.2$ & $21.9 \pm 3.5$ & $10.7 \pm 3.4$ & $34.42 \pm 0.3$ & $2.192 \pm 0.11$ \\
\hline \multirow{3}{*}{3} & \multirow{3}{*}{ Catla Catla } & Rainy & $29.9+2.6$ & $25.6 \pm 3.7$ & $14.8+3.9$ & $35.00 \pm 0.17$ & $2.415 \pm 0.49$ \\
\hline & & Winter & $28.5 \pm 5.4$ & $28.6 \pm 2.8$ & $11.7 \pm 4.0$ & $34.76 \pm 0.21$ & $2.498 \pm 0.05$ \\
\hline & & Summer & $24.3 \pm 2.9$ & $29.6 \pm 4.4$ & $9.4 \pm 2.3$ & $34.06 \pm 0.32$ & $2.698 \pm 0.79$ \\
\hline \multirow{3}{*}{4} & \multirow{3}{*}{ Cyprinous Carpio } & Rainy & $24.3 \pm 1.8$ & $26.8 \pm 2.2$ & $11.8 \pm 3.2$ & $38.0 \pm 1.3$ & $1.987 \pm 0.82$ \\
\hline & & Winter & $22.1 \pm 2.1$ & $24.2 \pm 3.4$ & $16.9 \pm 2.1$ & $33.7 \pm 3.2$ & $2.054 \pm 0.82$ \\
\hline & & Summer & $23.6 \pm 1.5$ & $21.3 \pm 2.2$ & $18.0 \pm 4.4$ & $32.6 \pm 2.1$ & $2.063 \pm 0.58$ \\
\hline
\end{tabular}


International Journal of Trend in Scientific Research and Development (IJTSRD) ISSN: 2456-6470

Table.4 Bio-chemical Composition in Liver of three major carps and a minor carp collected from Tawa Reservoir.

\begin{tabular}{|c|c|c|c|c|c|c|c|}
\hline Sr. No. & Fish Species & Season & Protein & Glycogen & Lipid & Moisture & LSI \\
\hline \multirow{3}{*}{1} & \multirow{3}{*}{ Cirrhinus Mrigala } & Rainy & $22.3 \pm 2.2$ & $28 \pm 2.8$ & $16.6 \pm 5.7$ & $39.35 \pm 1.23$ & $2.175 \pm 0.35$ \\
\cline { 3 - 8 } & & Winter & $29.3 \pm 1.5$ & $25.8 \pm 3.3$ & $19.8 \pm 2.1$ & $35.00 \pm 0.89$ & $2.192 \pm 0.26$ \\
\cline { 3 - 8 } & & Summer & $28.5 \pm 3.5$ & $28.7 \pm 2.9$ & $17.4 \pm 4.4$ & $32.06 \pm 0.63$ & $2.247 \pm 0.19$ \\
\hline \multirow{3}{*}{2} & \multirow{3}{*}{ Labeo Rohita } & Rainy & $28.7 \pm 3.8$ & $28.7 \pm 5.6$ & $18.9 \pm 7.2$ & $38.61 \pm 0.75$ & $2.018 \pm 0.25$ \\
\cline { 3 - 8 } & & Winter & $23.6 \pm 4.3$ & $22.4 \pm 2.6$ & $14.6 \pm 3.2$ & $37.68 \pm 0.12$ & $2.078 \pm 0.22$ \\
\cline { 3 - 8 } & & Summer & $20.4 \pm 2.5$ & $24.6 \pm 1.3$ & $10.3 \pm 3.2$ & $37.05 \pm 0.16$ & $2.123 \pm 0.26$ \\
\hline \multirow{3}{*}{3} & \multirow{3}{*}{ Catla Catla } & Rainy & $18.2 \pm 2.2$ & $26.8 \pm 4.3$ & $18.5 \pm 3.2$ & $38.01 \pm 1.03$ & $2.237 \pm 0.18$ \\
\cline { 3 - 8 } & & Winter & $24.0 \pm 5.6$ & $29.7 \pm 1.4$ & $11.8 \pm 4.2$ & $37.82 \pm 1.26$ & $2.398 \pm 0.11$ \\
\cline { 3 - 8 } & & Summer & $28.3 \pm 2.2$ & $21.8 \pm 2.2$ & $19.6 \pm 2.3$ & $34.62 \pm 0.62$ & $2.402 \pm 0.17$ \\
\hline \multirow{3}{*}{4} & \multirow{3}{*}{ Cyprinous Carpio } & Rainy & $22.13 \pm 1.5$ & $26.7 \pm 2.4$ & $18.5 \pm 1.4$ & $32.5 \pm 1.5$ & $1.023 \pm 0.14$ \\
\cline { 3 - 7 } & & Winter & $24.50 \pm 2.3$ & $25.6 \pm 2.1$ & $14.6 \pm 2.0$ & $31.6 \pm 2.0$ & $1.345 \pm 0.22$ \\
\cline { 3 - 7 } & & Summer & $22.6 \pm 2.2$ & $23.2 \pm 1.6$ & $19.5 \pm 1.6$ & $30.02 \pm 0.6$ & $1.673 \pm 0.13$ \\
\hline
\end{tabular}

